
2

3 5

6

7

8

9

\section{The influence of climate change related factors on the response of two clam} species to Diclofenac
4 5 7 8 Portugal

9

10

13

4

5

Corresponding author: Rosa Freitas

\begin{abstract}
Address: Departamento de Biologia, Universidade de Aveiro
\end{abstract}
Campus Universitário de Santiago

3810-193 Aveiro, Portugal

e-mail address: rosafreitas@ua.pt Amadeu M.V.M. Soares ${ }^{a}$, Rosa Freitas ${ }^{a^{*}}$, Montserrat Soléd

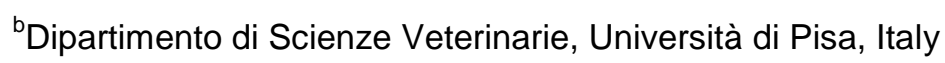

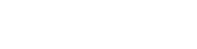

Silvana Costa ${ }^{a}$, Francesca Coppola ${ }^{a}$, Carlo Pretti ${ }^{b, c}$, Luigi Intorre ${ }^{b}$, Valentina Meucci ${ }^{b}$

aDepartamento de Biologia \& CESAM, Universidade de Aveiro, 3810-193 Aveiro,

${ }^{\mathrm{c}}$ Consorzio per il Centro Interuniversitario di Biologia Marina ed Ecologia Applicata “G. 


\section{Abstract}

The present study aimed to comparatively assess the effects caused by a non-steroidal inflammatory drug Diclofenac (DIC) in the clams Ruditapes philippinarum and Ruditapes decussatus and evaluate if these impacts were influenced by $\mathrm{pH}$ and temperature. Organisms were acclimated for 30 days at two different temperature and $\mathrm{pH}$ (control conditions: $\mathrm{pH}$ 8.1, $17^{\circ} \mathrm{C}$; climate change forecasted scenario: $\mathrm{pH} 7.7,20^{\circ} \mathrm{C}$ ) in the absence of drugs (experimental period I) followed by a 7 days exposure under the same water physical parameters but in absence or presence of the pharmaceutical drug (at $1 \mu \mathrm{g} / \mathrm{L}$, experimental period II). Biochemical responses covering metabolic capacity, oxidative stress and damage-related biomarkers were contrasted in clams at the end of the second experimental period. The results showed that under actual conditions, $R$. philippinarum individuals exposed to DIC presented enhanced antioxidant activities and reduced their respiration rate compared with non-contaminated clams. When exposed to the predicted climate change conditions, a similar response was observed in contaminated clams, but in this case clams increased their metabolic activities probably to fight the stress caused by the combination of both stressors. When $R$. decussatus was exposed to DIC, even at actual $\mathrm{pH}$ and temperature conditions, their antioxidant defences were also elevated but their baseline enzymatic activities were also higher in respect to $R$. philippinarum. Although both clams may use different strategies to prevent DIC damage, both clam species showed under low $\mathrm{pH}$ and high temperature limited oxidative stress impacts in line with a lower DIC bioaccumulation.

50

Keywords: Pharmaceuticals; bivalves; respiration rate; metabolic capacity; oxidative stress; Ruditapes clams. 


\section{INTRODUCTION}

The continuous release of carbon dioxide $\left(\mathrm{CO}_{2}\right)$ to the atmosphere is described as one of the main contributors for the global climate change (CC) currently observed (Solomon et al., 2009). The increasing atmospheric $\mathrm{CO}_{2}$ concentration has permitted this molecule to reach aquatic ecosystems and consequently decrease the average pH of oceans (Feely at al., 2009) and, it is predicted to decrease by up to $0.4 \mathrm{pH}$ units in 2100 (IPCC, 2014). Such pH decrease in aquatic systems has already proved to impact its fauna, namely in terms of their physiological and biochemical performances (Almeida et al., 2018; Berge et al., 2006; De Marchi et al., 2017; Matoo et al., 2013; Michaelidis et al., 2005; Moreira et al; 2018a; Munari et al., 2016; 2018; Nardi et al., 2017).

In addition to the predicted ocean acidification, earth surface temperature is also foreseen to rise up to $4^{\circ} \mathrm{C}$ (IPCC, 2014) by the end of the $21^{\text {st }}$ century, as a consequence of global warming caused mainly by the extensive emissions of greenhouse gas (e.g., $\mathrm{CO}_{2}$ and methane $\left(\mathrm{CH}_{4}\right)$ ) (Liu, 2019). Previous studies have already demonstrated that a rise in temperature will strongly affect marine organisms mainly in terms of growth and reproduction (Fabbri et al., 2014; Moreira et.al, 2018b, Moreira et al., 2018c) but also in regard to biochemical and metabolic processes (Almeida et al., 2018; Freitas et al.,2017; Maulvault et al., 2018; Matoo et al., 2013). range of anthropogenic compounds in addition to the former CC related stressors. Among these compounds, pharmaceuticals and personal care products (PPCPs), have become an emerging concern in environmental safety, as a result of their increasingly worldwide presence in aquatic systems at concentration from $\mathrm{ng} / \mathrm{L}$ to $\mu \mathrm{g} / \mathrm{L}$ (Daughton and Ternes, 1999; Fent et al., 2006; Gaw et al., 2014; Kolpin et al., 2002; Metcalfe et al., 2003; Santos et al., 2010). The presence of PPCPs in aquatic systems derives from their use in agriculture, human and veterinary applications as well as from effluents from waste disposal sites (Henschel et al., 1997). Among pharmaceuticals, diclofenac (DIC) is one of the non-steroidal anti-inflammatory drugs (NSAID) with higher consumption rates, used in both human and veterinary medicine (Fent et al., 2006; 
unchanged (Landsdorp et al.,1990), reaching sewage treatment plant (STP) effluents and ultimately surface waters (Heberer, 2002; Lehmann, 2000; Ternes,1998; Ternes, 2001). Diclofenac is also found in marine, coastal and estuarine waters of Portugal (0.02 and 241 $\mathrm{ng} / \mathrm{L})$, Baltic Sea coast $(0.25-92.6 \mathrm{ng} / \mathrm{L})$, in USA $(0.25-0.6 \mathrm{ng} / \mathrm{L})$, and in the Chinese coast concentrations may reach up to $843 \mathrm{ng} / \mathrm{L}$ (Bonnefille et al., 2018). Although several studies already highlighted the negative impacts caused by DIC in aquatic organisms (Mezzelani, et al., 2016; Quinn et al., 2011; Schmidt et al., 2011; Schwaiger et al., 2004; Fontes et al., 2018; Gonzalez-Rey and Bebianno, 2014), scarce information is available on the combined effects of $\mathrm{CC}$ related factors (e.g. $\mathrm{pH}$ ) on the responses and sensitivity of bivalves towards this drug (Munari et al., 2016, Munari et al., 2018). To the best of our knowledge, no studies evaluated the consequences of DIC exposure in bivalves under a realistic CC scenario of both temperature and $\mathrm{pH}$ acting in combination. Bivalves, including clams, are good indicators of marine environmental pollution, and offer a powerful tool in toxicology research, as previous studies already demonstrated the capacity of these species to reveal biological effects induced by different PPCPs (Almeida et al., 2018; Munari et al., 2016, 2018).

The aim of the study was to evaluate the impact of an acute DIC exposure (7 days) at an environmental relevant concentration $(1 \mu \mathrm{g} / \mathrm{L})$ upon two estuarine clams previously acclimated to actual conditions and those predicted under a CC scenario (for 30 days). To this end, biochemical markers related to clam's metabolic capacity, oxidative and neurotoxic status were evaluated including respiration rate as a physiological indicator. The present study also aimed to predict, if under a competitive situation which of the two clam species used, the European clam $R$. decussatus (native) and the Manila clam, R. philippinarum (invasive), would be more competitive under a future climate scenario of combined warming and acidification conditions. 


\section{MATERIALS AND METHODS}

2.1 Species collection and experimental setup

Individuals from the clam species $R$. decussatus and $R$. philippinarum were collected from the Ria de Aveiro (NW coast of Portugal), transported to the laboratory and maintained in artificial seawater for two weeks for depuration and adaptation to laboratory conditions: temperature (17 $\stackrel{\circ}{\circ})$, salinity (30) and photoperiod (12 light:12 dark). Clams were not fed during the first week while during the second one they were feed every other day with Algamac protein plus (150.000cells/animal).

After depuration and acclimation, clams were kept for 30 days under two scenarios: A) actual conditions in the field at the sampling time $\left(\mathrm{pH} 8.1,17^{\circ} \mathrm{C}\right)$ and $\left.\mathrm{B}\right)$ mimicking $\mathrm{CC}$ condition $\left(\mathrm{pH} 7.7,21^{\circ} \mathrm{C}\right)$ - experimental period I. After this time half of each group (A and $\mathrm{B}$ ) was maintained uncontaminated and the other half was exposed to $1 \mu \mathrm{g} / \mathrm{L}$ of Diclofenac (DIC) for 7 days (keeping the respective water conditions of temperature and $\mathrm{pH}$ of each condition). Thus, resulting into 4 different situations per species: 1) $\mathrm{pH} 8.1$ and $17^{\circ} \mathrm{C}$ in the absence of DIC; 2) same $\mathrm{pH}$ and temperature but with $\mathrm{DIC}$; 3) lower $\mathrm{pH} 7.7$ and higher temperature $21^{\circ} \mathrm{C}$ in the absence of the drug and 4) same CC conditions in the presence of DIC. During these 7 days exposure period (experimental period II) water was renewed every 2 days, followed by DIC concentration reestablishment. Per treatment 3 replicate aquaria were used, with 7 specimens per aquarium (21 per condition, 42 per climate scenario).

During the experimental period II water samples were collected immediately after spiking to confirm drug concentration in water. During experimental periods I and II immediately after and before water renewal, water samples $(50 \mathrm{~mL})$ were collected to determine the physicochemical parameters of the used water. Temperature $\left(\mathrm{T}\left({ }^{\circ} \mathrm{C}\right)\right), \mathrm{pH}$ and salinity $(\mathrm{S})$ were measured and total alkalinity (TA) determined for each water sample by potentiometric titration (Gran, 1952). Obtained TA values, temperature and salinity were used to determine $\mathrm{CO}_{2}$ partial pressure $\left(\mathrm{pCO}_{2}\right)$, bicarbonate $\left(\mathrm{HCO}^{3}\right)$ and carbonate $\left(\mathrm{CO}_{3}^{2}\right)$ ions concentrations, and the saturation states of calcite $(\Omega \mathrm{Cal})$ and aragonite $(\Omega \mathrm{Ag})$ for each aquarium. These concentrations were calculated using CO2SYS software (Robbins et al., 2010), with K1 and K2 carbonate 
dissociation constants (Mehrbach et al., 1973) refit by Dickson and Millero (1987), and KSO4 from Dickson (1990).

After 37 days ( 30 days acclimation to different climate scenarios - experimental period I +7 days - drug exposure, experimental period II), unexposed and contaminated clams from the 2 scenarios (3 organisms per aquarium, 9 per condition) were immediately frozen in liquid nitrogen and preserved at $-80 \stackrel{\circ}{C}$ until being processed. The organisms aimed for biochemical analysis were individually pulverized with liquid nitrogen, divided into $0.3 \mathrm{~g}$ aliquots of fresh weigh $(\mathrm{FW})$ and stored at $-80^{\circ} \mathrm{O}$. Some other specimens were stored at $-20^{\circ} \mathrm{C}$ for $\mathrm{DIC}$ quantification. The remaining organisms were used to evaluate the respiration rate (RR) and then further used to determine lipid content (LIP).

\subsection{Quantification of diclofenac concentrations in water and soft tissue of clams}

Concentrations of DIC were measured in water and soft tissues by using high performance liquid chromatography-ultraviolet (HPLC-UV) detection method. Water samples were analyzed following Madikizela et al. (2017) method with slightly modifications. Water samples $(100 \mathrm{~mL}$ ) were extracted by solid phase extraction (Oasis MAX 6cc $150 \mathrm{mg}$ solid phase extraction cartridges, Waters). The $\mathrm{pH}$ of water samples was adjusted to 2.5 , and then, $100 \mathrm{~mL}$ of each sample was loaded onto a pre-conditioned cartridge. The SPE cartridge was rinsed with methanol : water (10:90\%, v:v) prior to sequential elution of retained DIC with $2 \mathrm{~mL}$ methanol, followed by $2 \mathrm{~mL}$ methanol and acetic acid (90:10, v:v) and $2 \mathrm{~mL}$ of $2 \%$ (v:v) formic acid diluted using a mixture of methanol and acetic acid (40:60, v:v) final volume (6 mL). Eluted samples were evaporated to dryness with nitrogen gas in an evaporation set-up at room temperature and reconstituted with $0.2 \mathrm{~mL}$ of HPLC mobile phase. Soft tissues samples were were extracted according to Gatidou et al. (2007) with slightly modifications. Tissue samples (1.5 g) were dehydrated in an oven at $60^{\circ}$ overnight and sonicated at $50{ }^{\circ} \mathrm{C}$ for 30 min using $16 \mathrm{~mL}$ of mixture of methanol $(10 \mathrm{~mL})$ and Milli- $\mathrm{Q}$ water $(6 \mathrm{~mL})$ as the extraction solvent. The supernatant was collected after centrifugation and diluted to a final volume of $100 \mathrm{~mL}$ using 166 Milli-Q grade water and then purified with solid phase extraction as reported for water samples. The chromatographic system consisted of a Series 200 PerkinElmer gradient pump coupled to a 
91

Series 200 PerkinElmer variable UV detector, which was set at $280 \mathrm{~nm}$. The mobile phase consisted of acetonitrile and $0.2 \%$ formic acid in water, at a ratio of $60: 40$ (v:v). A 100- $\square \mathrm{L}$ injection was used each time. The reversed-phase column was a Haisil, LC column (5 $\square \mathrm{m}$, 150x4.60 mm, Higgins). The column was kept at room temperature. Turbochrome software was used for data processing. DIC was quantified in calibration curves prepared in HPLC mobile phase and in water and soft tissues without DIC to assess the influence of the sample matrix on the analyte quantification. No matrix effect was observed by comparing the difference between the measurements obtained in triplicate in different matrices. The recovery was $>80 \%$ for water samples and $>77 \%$ for soft tissues. The detection limit, calculated as a signal-to-noise ratio of $3: 1$, was $0.10 \mu \mathrm{g} / \mathrm{l}$ for water samples and $5 \mathrm{ng} / \mathrm{g}$ dry weight for soft tissues.

\subsection{Physiological parameters}

Respiration rate (RR) was assessed at the end of the 37-day experimental period. Two organisms per replicate aquarium were selected at each condition $(n=6)$ and thus, 12 individuals per species. Measurements were performed by simple static respirometry using 2 specimens of the same aquarium per chamber. Each of these chambers was equipped with an oxygen sensor spot glued to its inner wall using silicon paste, and filled with the same seawater used during the experiment. Organisms were placed in these chambers under dark and fully-oxygenated concentrations and were allowed to acclimate for $30 \mathrm{~min}$ to avoid the influence of manipulation. After this period, chambers were filled to their maximum capacity $(1 \mathrm{~L})$, to prevent the formation of air bubbles and were air-tight sealed. Measurements started in a fully oxygenated medium and RR was recorded as a function of declining $\mathrm{O}_{2}$ concentration $(\mathrm{mg} / \mathrm{L})$ over time recorded every 15 min during $2 \mathrm{~h}$, using a multi-channel fiber optic oxygen meter (Multi channeloxygen meter, PreSens $\mathrm{GmbH}$, Regensburg, Germany) for simultaneous read-outs. Data were recorded using the software PreSens Measurement Studio 2. Twenty-two measurements were carried out at a time (including a blank, i.e. chamber containing no organisms to account for background oxygen loss).

\subsection{Biochemical parameters}


The biochemical parameters analysed included metabolic capacity (electron transport system activity, ETS) and energy reserves (glycogen GLY; protein, PROT; lipid, LIP) contents, antioxidant defences (superoxide dismutase, SOD; catalase, CAT; glutathione peroxidase, GPx; glutathione S-transferases, GSTs) activities and effect markers (lipid peroxidation, LPO; protein carbonylation, PC, reduced (GSH) and oxidized glutathione (GSSG) concentrations, and the activity of Acetylcholinesterase (AChE) as a neurotoxicity marker. Determinations were conducted at room temperature and each sample replicate $(n=9)$ was analysed at least in duplicate and accompanied by blanks and standard samples (when applicable) for quality control.

The extraction for each biomarker was done with specific buffers (see Andrade et al., 2019; Coppola et al., 2019). For this, samples were homogenized for $30 \mathrm{~s}$ at $4{ }^{\circ} \mathrm{C}$ and centrifuged for $10 \mathrm{~min}$ at $10,000 \mathrm{~g}$ (or $3,000 \mathrm{~g}$ for ETS) at $4 \stackrel{\circ}{\circ}$. Supernatants were stored at -80 $\stackrel{\circ}{\circ}$ or immediately used.

\subsubsection{Metabolic capacity and energy related biomarkers}

The activity of ETS was measured following King and Packard (1975) and De Coen and Janssen (1997) methods. The absorbance was read at $490 \mathrm{~nm}$ during 10 min with intervals of $25 \mathrm{~s}$. The amount of formazan formed was calculated using $\varepsilon=15,900 \mathrm{M}^{-1} \mathrm{~cm}^{-1}$ and the results expressed in $\mathrm{nmol} / \mathrm{min}$ per $\mathrm{g}$ of $\mathrm{FW}$.

The GLY content was quantified according to the sulphuric acid method from Dubois et al. (1956), using glucose standards $(0-5 \mathrm{mg} / \mathrm{mL})$. The absorbance was measured at $492 \mathrm{~nm}$. The concentration of GLY was expressed in mg per $\mathrm{g}$ of FW.

The PROT content was determined using bovine serum albumin (BSA) as standard (0-40 $\mathrm{mg} / \mathrm{mL}$ ), following the Biuret method (Robinson et al., 1940). The absorbance was measured at $540 \mathrm{~nm}$. Concentration of PROT reserves was expressed in mg per $\mathrm{g}$ of FW.

The LIP content was quantified according Cheng et al. (2011). Absorbance was measured at $540 \mathrm{~nm}$ after $1 \mathrm{~h}$ of colour development. Results were expressed in percentage per g dry weight (DW). 


\subsubsection{Oxidative stress biomarkers}

The activity of SOD was determined by using the method described in Beauchamp et al. (1971) and adaptations performed by Carregosa et al. (2014). The standard curve was determined using SOD standards $(0-60 \mathrm{U} / \mathrm{mL})$. Absorbance was read at $560 \mathrm{~nm}$ after $20 \mathrm{~min}$ of incubation at room temperature. Results were expressed in $\mathrm{U}$ per g FW where one unit (U) represents the quantity of the enzyme that catalyzes the conversion of $1 \mu \mathrm{mol}$ of substrate per $\min$.

The activity of CAT was quantified according to Johansson et al. (1988) and after the modifications performed by Carregosa et al. (2014). The standard curve was determined using formaldehyde standards $(0-150 \mu \mathrm{M})$. The absorbance was measured at $540 \mathrm{~nm}$. The enzymatic activity was expressed in $U$ per $g$ of $F W$, where $U$ represents the amount of enzyme that caused the formation of $1.0 \mathrm{nmol}$ formaldehyde per min at $25^{\circ} \mathrm{C}$.

The activity of GPx was quantified following Paglia and Valentine (1967) protocol. The absorbance was measured at $340 \mathrm{~nm}$ at $10 \mathrm{sec}$ intervals during $5 \mathrm{~min}$ and the enzymatic activity was determined using $\varepsilon=6.22 \mathrm{mM}^{-1} \mathrm{~cm}^{-1}$. The results were expressed as $\mathrm{U}$ per $\mathrm{g} F \mathrm{~F}$, where $U$ represents the number of enzymes that caused the formation of $1.0 \mu$ mol NADPH oxidized per min.

The activity of GSTs was determined according to Habig et al. (1976). The absorbance was measured at $340 \mathrm{~nm}$. The activity of GSTs was determined using the extinction coefficient $\varepsilon=9.6 \mathrm{mM}^{-1} \mathrm{~cm}^{-1}$. The enzymatic activity was expressed in $\mathrm{U}$ per $\mathrm{g}$ of $\mathrm{FW}$ where $\mathrm{U}$ is defined as the amount of enzyme that catalysis the formation of $1 \mu \mathrm{mol}$ of dinitrophenyl thioether per min.

Non-enzymatic markers

Levels of LPO were measured according to Ohkawa et al. (1979) and modifications made by Carregosa et al. (2014). The absorbance was measured at $535 \mathrm{~nm}$. LPO levels were determined using the extinction coefficient $\varepsilon=156 \mathrm{mM}^{-1} \mathrm{~cm}^{-1}$ and the results were expressed in nmol of malonaldehyde (MDA) formed per $\mathrm{g}$ of FW. 
Levels of PC were quantified following the method described by Mesquita et al. (2014). Absorbance was measured at $450 \mathrm{~nm}$ using $\varepsilon=0.022 \mathrm{mM}^{-1} \mathrm{~cm}^{-1}$ and the results were expressed in nmol of protein carbonyl groups formed per $\mathrm{g}$ of FW.

Reduced (GSH) and oxidized (GSSG) glutathione content were determined according with Rahman et al. (2007), using reduced and oxidized glutathione standards $(0-60 \mu \mathrm{mol} / \mathrm{L})$. Absorbance was measured at $412 \mathrm{~nm}$, for both assays. The results were expressed as nmol per $\mathrm{g}$ of $\mathrm{FW}$. The ratio GSH/GSSG was determined taking in account the number of thiol equivalents (GSH/ $2 *$ GSSG).

258

\subsubsection{Neurotoxicity}

Acetylthiocholine iodide (ATChI $5 \mathrm{mM}$ ) substrates were used for the determination of Acetylcholinesterase (AChE) activity following the methods of Ellman et al. (1961) and modification by Mennillo et al. (2017). Enzyme activities were recorded continuously for 5 min at $412 \mathrm{~nm}$ and expressed in nmol per min per $\mathrm{g} F W$.

Data obtained from biochemical analyses and DIC concentrations were submitted to hypothesis testing using permutational multivariate analysis of variance with the PERMANOVA+add-on in PRIMER v6. The pseudo- $F$ values in the PERMANOVA main tests were evaluated in terms of significance. When the main test revealed statistical significant differences $(p \leq 0.05)$, pairwise comparisons were performed. The t-statistics in the pair-wise comparisons were evaluated in terms of significance. The null hypotheses tested for each parameter were: (I) for each climate scenario $\left(\mathrm{pH} 8.1,17^{\circ} \mathrm{C} ; \mathrm{pH} 7.7,21^{\circ} \mathrm{C}\right)$ and for each species (R. philippinarum; R. decussatus) no significant differences exist between non-contaminated 274 (absence of DIC) and contaminated (presence of DIC) organisms. For this hypothesis (I) significant differences $(p<0.05)$ between non-contaminated and contaminated organisms are represented in figures with an asterisk; (II) for each species and contamination level no significant differences exist between scenarios $\left(\mathrm{pH} 8.1,17^{\circ} \mathrm{C} ; \mathrm{pH} 7.7,21^{\circ} \mathrm{C}\right)$. For this hypothesis (II) significant differences between climate conditions are represented in figures with the symbol 
279 \#; (III) for each scenario and contamination level no significant differences exist between 280 species. For this last hypothesis (III) significant differences are identified in figures with a lower 281 case letter (for non-contaminated organisms) and an upper case letter (for DIC exposed 282 organisms).

283 The results regarding the physiological and biochemical responses per condition were 284 used to calculate the Euclidean distance similarity matrix. This matrix was simplified through the 285 calculation of the distance among centroids based on the eight conditions, which was then 286 submitted to ordination analysis, performed by Principal Coordinates (PCO). Pearson 287 correlation vectors $(r>0.85)$ of physiological and biochemical descriptors were provided as 288 supplementary variables being superimposed on the top of the PCO graph. 
3.1 Water characteristics and DIC presence in water and clams soft tissue

Water parameters for experimental periods I and II are detailed in Table 1. DIC concentrations measured in water from each aquarium, collected immediately after contamination, validated the spiking process of nominal desired concentration (1 $\mu \mathrm{g} / \mathrm{L})$, regardless of condition (Table 2). In the same Table 2 , for each climate scenario $\left(17^{\circ} \mathrm{C} \mathrm{pH} 8.1\right.$ vs $21^{\circ} \mathrm{C} \mathrm{pH}$ 7.7) concentrations of DIC in clams soft tissue revealed species differences in bioaccumulation with lower values in the European clam, $R$. decussatus, and DIC levels decreasing in both species at higher temperature and lower $\mathrm{pH}$ but reaching significance only for the Manila clam, R. philippinarum.

The present study revealed that under a predicted climate change (CC) scenario of increased temperature and lower $\mathrm{pH}$ both species accumulated lower DIC concentrations than under actual water conditions ( $17^{\circ} \mathrm{C}$ and $\mathrm{pH}$ 8.1), suggesting clams may develop strategies that may diminish the bioaccumulation of this drug. One of the reported mechanisms described to lower bioaccumulation is associated to reduction of the organism's respiration and filtration rate. In fact, Schiedek et al. (2007) predicted that under single and combined warming and acidification conditions, a decreased metabolism is observed in calcifying organisms, driven mainly by $\mathrm{pH}$ variations. However, since under the present experimental conditions of considering both variables together, as a more realistic approach, contaminated clams neither reduced their respiration rate (RR) nor their metabolism measured as ETS activity, these two mechanisms do not seem to apply to these clams. Clams neither increased the detoxification mechanisms (e.g. GSTs activity) under CC conditions. Thus, other hypothesis such as chemical properties of DIC under lower $\mathrm{pH}$ and higher temperature conditions which will render it less bioavailable to clams may apply. In fact, DIC is an acidic drug whose bioaccumulation capacity, measured as log Kow, decreases at a lower $\mathrm{pH}$, could partly explain the lower levels found in clams under a CC scenario. A recent study conducted with mussels also combining warming and acidification revealed a particular behaviour on the bioaccumulation of the seven PPCPS tested (but not considered DIC) which was temperature and pH dependent (Serra-Compte et al. 2018). Consistent with the former observations on DIC bioaccumulation in clams, lower levels of 
carbamazepine (CBZ) in the clams R. philippinarum (Almeida et al. 2018b) and Scrobicularia plana at lower pH (Freitas et al. 2015) were also described. Moreover, the amount of DIC detected in clams in the present exposure conditions $(24-90 \mathrm{ng} / \mathrm{g} \mathrm{dw})$ falls within the range of this same drug accumulated in mussels under the equivalent $1 \mathrm{ug} / \mathrm{L}$ water nominal concentration (Ericson et al., 2010; Freitas et al., 2019a, 2019b).

\subsection{Physiological parameters}

After the 30-day acclimation at control conditions a mortality rate of $9.6 \%$ ( $R$. decussatus) and $1.5 \%$ (R. philippinarum) was recorded. When acclimated to climate change conditions, only R. decussatus specimens died (22.8\%). In contrast, 7 - day exposure to DIC caused mortality in R. philippinarum (6.7\%) at the control scenario.

The Manila clam, R. philippinarum, decreased significantly their respiration rate (RR) when exposed to $\mathrm{DIC}$ at actual conditions $\left(17^{\circ} \mathrm{C}\right.$ and $\left.\mathrm{pH} 8.1\right)$, however this activity significantly increased when exposed to the same drug but under warming and acidified conditions in respect to those also contaminated but under the present scenario (Figure 1). The European clam, R. decussatus, was neither affected by DIC exposure nor CC predictions in terms of RR. Differences between species were only revealed at actual conditions in presence of DIC, with higher RR values recorded in the European clam (Figure 1).

Despite higher RR in the Manila clam under forecasted climate change conditions and in European clams in the control ambient situation, the bioaccumulation of DIC did not reflect this trend pattern. Thus confirming bioaccumulation is more species-dependent than climatedriven, more importantly in the European clam. Almeida et al. (2015) also demonstrated that for the same clam species, $R$. philippinarum, the clearance rate decreased with increasing exposure to CBZ, revealing a behaviour reaction of Manila clam to drug insults. Such response may suggest that under higher stressful conditions (drug and $\mathrm{CC}$ ) this clam species adopts a different strategy by increasing their RR probably associated with higher metabolism to fuel up defence mechanisms, as further corroborated by ETS activity. Former studies with bivalves already demonstrated that under stress situations such as low $\mathrm{pH}$ and/or high temperature 
aquatic organisms such as bivalves increase their RR rate (Andrade et al., 2019; Freitas et al., 2017b; Gestoso et al., 2016; Xu et al., 2017).

3.3 Biochemical parameters

\subsubsection{Metabolic capacity and energy related biomarkers}

Electron transport system (ETS) activity presented a significant increase in contaminated

R. philippinarum specimens under the two scenarios. When comparing both species at the same condition, a consistent higher ETS activity was observed for $R$. decussatus except when exposed to DIC under a CC situation (Figure 2A).

Glycogen (GLY) content was enhanced after 7 day DIC exposure in $R$. philippinarum under actual conditions ( $17^{\circ} \mathrm{C}$ and $\mathrm{pH}$ 8.1) but, this same species, experienced a decrease in GLY content when under CC conditions. Species contrasts revealed that $R$. decussatus presented higher GLY content in respect to its sympatric species the Manila clam in the noncontaminated specimens under both climate scenarios and also in contaminated clams but only at CC conditions (Figure 2B).

The protein (PROT) content decreased significantly in $R$. philippinarum exposed to DIC regardless climate condition. Differences exclusively due to water conditions in PROT content were only observed in control and contaminated $R$. decussatus. Species contrasts confirmed consistent lower reserve values in $R$. decussatus at both scenarios (Figure 2C).

Lipid (LIP) reserves revealed differences between non-contaminated $R$. decussatus specimens under the two climatic scenarios, with lower reserves at forecasted CC conditions. As far as species contrasts concerns, significantly higher LIP content was observed in $R$. decussatus regardless of exposure only at actual water conditions (Figure 2D).

Diclofenac exposure alone had no influence on clam's metabolic capacity (ETS) at any of the tested conditions suggesting that the concentration of DIC used was not enough to influence on clams metabolism and the inclusion of an additional factor, such as CC conditions, was required to cause a response in this parameter in the clam R. philipinarum (as indicated above).

375 Other studies in the same clam species assessing the impacts of caffeine $(0.3-18.0 \mu \mathrm{g} / \mathrm{L})$ revealed no modulation in ETS activity at the lower drug concentrations (Cruz et al. 2016). 
Nevertheless, in what regards to energy reserves it seems that, at a small extent, the presence of DIC neither affected nor enhanced the expenditure of GLY and on the contrary was responsible for decreased PROT levels in DIC-exposed $R$. philippinarum with no impacts on $R$. decussatus, a response that was independent on the climate scenario tested. By contrast, Nunes et al. (2017) reported a decrease in GLY reserves when R. philippinarum was exposed to paracetamol. Other reserves, such as LIP content, were unaffected in R. philippinarum at all tested conditions but, in the European clam, $R$. decussatus, a decrease in this fuel content was seen under CC conditions regardless of drug presence. Other studies with $R$. philippinarum reported a decrease in LIP content when exposed to reduced pH (Velez et al. 2016b) and in this same bivalve 7 day exposure to functionalized and non-functionalized carbon nanotubes $(0.01$ $1.00 \mathrm{mg} / \mathrm{L}$ ) did not induce any changes in LIP content when considering low levels of nanomaterial (De Marchi 2018).

\subsubsection{Enzymatic oxidative stress biomarkers}

Superoxide dismutase (SOD) activity significantly increased in DIC exposed $R$. decussatus under the actual and predicted climate situations. Differences between climate scenarios were also confirmed in R. decussatus contaminated clams, with lower activities at the forecasted conditions, with species differences only achieved at this condition (Figure 3A). Catalase (CAT) activity was also significantly enhanced in $R$. decussatus exposed to DIC at both climate scenarios. This activity also significantly increased in $R$. philippinarum under warming and acidified conditions, while the opposite trend was seen in $R$. decussatus. As far as species contrasts concerns, significantly higher CAT activity was seen in R. decussatus for most situations (Figure 3B). Glutathione peroxidase (GPx) activity was elevated in DIC exposed $R$. decussatus in both climate scenarios. In terms of species contrasts, this activity was consistently higher in the European clam regardless of drug exposure and climate situation (Figure 3C). Glutathione-S-transferases (GSTs) activity was significantly elevated in contaminated organisms of both species at higher temperature and lower $\mathrm{pH}$ conditions. The most significant result was the consistently higher defence GST activity displayed by the European clam (Figure 3D). 
Exposure to DIC caused an overall activation of antioxidant and biotransformation enzymes regardless the climate scenario. Contrarily to the little influence of this drug on modulating energetic parameters, DIC exposure activated defence mechanisms in clams and more importantly in the European clam. Other bivalve studies, such as that conducted by Munari et al. (2018) also observed higher SOD activity when the clam R. philippinarum was exposed to DIC for 7 days, and Quinn et al. (2011) showed increased GSTs activity in the freshwater mussel, Dreissena polymorpha, exposed to DIC after $24 \mathrm{~h}$ and $96 \mathrm{~h}$. Exposing $R$. philippinarum and $R$. decussatus to $\mathrm{CBZ}$ and cetirizine (CTZ) also revealed increased antioxidant and biotransformation activities in both species (Almeida et al. 2014; 2015; 2017) although when $R$. philippinarum was exposed to $\mathrm{CBZ}$ and $\mathrm{CTZ}$ at several water $\mathrm{pH}$, GPX was not affected (Almeida et al. 2018).

Despite regardless of environmental scenario the enzyme defences increased, the present results further revealed that increased temperature and lower $\mathrm{pH}$ (CC scenario) affected negatively the activities of CAT and SOD by decreasing their antioxidant capacity in $R$. decussatus while these enzymes were not compromised in $R$. philippinarum. Current observations may further suggest a higher sensitivity of $R$. decussatus to drugs in the presence of warming and acidified conditions. However, since the overall enzymatic activity load, in terms of GPX, CAT and most significantly GST, was much greater in the European clam, this species could face the anthropogenic insults thanks to a superior overall antioxidant capacity. Moreover, in terms of species contrasts, lower LPO levels were consistently found in $R$. decussatus (Figure 4A). In terms of oxidized protein formation, significantly lower PC values were also observed in control as well as DIC exposed $R$. decussatus under forecasted conditions. But, consistently higher PC levels were always revealed in $R$. decussatus, regardless contamination level and climate conditions (Figure 4B). 
contaminated organisms of both species under the actual climatic parameters, while it increased in $R$. philippinarum at the forecasted conditions. Differences due to climate scenarios were confirmed in unexposed $R$. philippinarum and contaminated $R$. decussatus; while this ratio decreased in the former Manila clam, it increased in the latter European clam at the forecasted CC scenario. Significant differences between species were only observed for non-contaminated organisms at the present climate situation $\left(17^{\circ} \mathrm{C}\right.$ and $\mathrm{pH}$ 8.1) with the lower $\mathrm{GSH} / \mathrm{GSSG}$ ratio for R. decussatus (Figure 4C).

The enhanced antioxidant defences, formerly described after DIC exposure, seemed to be sufficient to prevent LPO occurrence in both clam species. Moreover, in accordance to a higher antioxidant pool in $R$. decussatus, LPO levels were consistently lower in this species. By contrast, in terms of protein damage, the extent of PC occurrence was greater in the European clam regardless of environmental conditions and DIC presence. Former studies in clams by Almeida et al. (2014) showed no changes on LPO levels when the bivalves were exposed to low concentrations of CBZ. Also, Munari et al. (2018) did not recorded any significant difference for LPO levels in clams and mussels exposed to DIC at different conditions of acidification. However, the consistent decrease on the GSH/GSSG ratio in contaminated organisms of both clam species, even at the actual environmental conditions, confirms that DIC bioaccumulated in clams' tissue was responsible for an oxidative stress condition. The fact that this response was not mirrored in exposed clams under the forecasted CC conditions, could be explained by the lower presence of DIC in their tissues. Former studies with mussels exposed to the same DIC water concentration of $1 \mu \mathrm{g} / \mathrm{L}$, confirmed that this drug consistently reduced the antioxidant GSH/GSSG balance (Freitas et al., 2019a; 2019b).

\subsubsection{Marker of neurotoxicity}

Significant differences between non-contaminated and contaminated clams in AChE activity were only identified in $R$. decussatus under a CC situation. Both DIC exposed species presented significantly higher AChE values under forecasted conditions, while in the case of unexposed $R$. decussatus this activity decreased. Differences between species were confirmed at all conditions with higher activity always determined in the European clam (Figure 5). 
Increased in AChE activity in both species was more likely a response to increased temperature and decreased water $\mathrm{pH}$ than to DIC exposure. Rosa et al. (2016) also observed an increasing on AChE activity when assessing the neuro-oxidative damage of sharks' brain cells under climate change conditions. In agreement with this data, also Durieux et al. (2011) observed a strong relationship between temperature and this enzymatic activity in fish. Moreover, increase in this esterase activity can be also the result of apoptosis due to stressful environmental conditions (Zhang et al., 2002). Nonetheless, as pointed out formerly by the higher antioxidant enzymatic pool and ETS activity, elevated AChE activities in $R$. decussatus than in $R$. philippinarum, could only indicate species-dependent baseline values. In clams, the measurement of AChE activity is controversial since the measured activity under the most currently adopted $1 \mathrm{mM}$ substrate concentrations is low (Volvonesi et al., 2003; Solé et al., 2018). However, in this study, the use of a higher 5 mM ATC substrate concentration allowed for the detection of drug and water characteristics responses and confirmed species differences.

The use of multivariate tools is highly recommended when multiple conditions and variables are contrasted such is this case study. Principal coordinates analysis (PCO) is shown in Figure 6. PCO axis 1 explained almost $65 \%$ of total variation, while PCO axis 2 contributed with about $14 \%$. PCO1 clearly separated $R$. decussatus individuals at the positive side from $R$. philippinarum individuals at the negative side. PCO2 separated individuals of both species exposed to $\mathrm{DIC}$ at present conditions $\left(17^{\circ} \mathrm{C}\right.$ and $\mathrm{pH}$ 8.1) together with those non-contaminated of $R$. philippinarum under a climate change scenario $\left(21^{\circ} \mathrm{C}\right.$ and $\left.\mathrm{pH} 7.7\right)$ in negative side of the axis from the remaining conditions allocated in the positive side. GSTs, AChE, ETS, GPx, CAT and PC were the biomarkers positively correlated to PCO $1(r>0.85)$ while PROT showed a high negative correlation ( $r>-0.85)$ in the same axis. The GSH/GSSG ratio was positively correlated with PCO2 $(r>0.7)$. A clear separation of the species in the axes corroborated species differences with higher enzyme activities recorded in the European clam while greater responses to DIC exposure were observed in the Manila clam mostly under a CC scenario. 


\section{CONCLUSION}

Despite the ample set of biomarkers and conditions tested in two clam species revealed complex responses, which were in turn species-, drug- and environmentally-dependent, some consistent outcomes can be settled. Exposure to DIC was more relevant in terms of antioxidant defences modulation than affecting the energetic and reserves pathways. Baseline ETS, antioxidant and AChE activities were overall greater in $R$. decussatus (European clam) than in the R. philippinarum (Manila clam). Although in both species oxidative damage was prevented, baseline LPO levels were higher in the Manila clam while higher oxidised protein (PC) occurrence was found in the European clam. A predicted $\mathrm{CC}$ scenario of reduced $\mathrm{pH}$, higher temperature together with drug exposure induced some behaviour (respiration rate) and metabolic responses that efficiently reduced the DIC bioccumulated in clams tissue and therefore the negative consequences of drug exposure. Moreover, the PCO integration tool confirmed species differences and a greater response in the Manila clam to DIC exposure at further environmental challenges, which may facilitate the replacement of the native by the invasive species.

509

\section{Acknowledgements}

Francesca Coppola benefited from a PhD grant (SFRH/BD/118582/2016) given by the 512 National Funds through the Portuguese Science Foundation (FCT), supported by FSE and 513 Programa Operacional Capital Humano (POCH) e European Union. Rosa Freitas was funded 514 by national funds (OE), through FCT - Fundação para a Ciência e a Tecnologia, I.P., in the 515 scope of the framework contract foreseen in the numbers 4,5 and 6 of the article 23 , of the 516 Decree-Law 57/2016, of August 29, changed by Law 57/2017, of July 19 . Thanks are due for 517 the financial support to CESAM (UID/AMB/50017/2019), to FCT/MEC through national funds, 518 and the co-funding by the FEDER, within the PT2020 Partnership Agreement and Compete 519 2020. This work was also financially supported by the project BISPECIAl: BlvalveS under 520 Polluted Environment and Cllmate chAnge (POCI-01-0145-FEDER-028425) funded by FEDER, through COMPETE2020 - Programa Operacional Competitividade e Internacionalização 
522 (POCl), and by national funds (OE), through FCT/MCTES; and by the Spanish Ministry of 523 Economy, Industry and Competitivity: AimCost project (ref CGL2016-76332-R 524 MINECO/FEDER/UE). The authors also acknowledge to the RED RIESCOS - Evaluación de los 525 Efectos de los Contaminantes Emergentes en Organismos Acuáticos y sobre la Salud Humana, 526 from the Programa Iberoamericano de Ciencia y Tecnología para el Desarrollo (CYTED) with the reference 419RT0578.

\section{REFERENCES LIST}

Almeida, A., Calisto, V., Esteves, V.I., Schneider, R.J., Soares, A.M.V.M., Figueira, E., Freitas, R. (2017). Ecotoxicity of the antihistaminic drug cetirizine to Ruditapes philippinarum clams. Sci. Total. Environ., 601-602, 79.3-801.

Almeida, A., Calisto, V., Esteves, V.I., Schneider, R.J., Soares, A.M.V.M., Figueira, E., Freitas, R. (2014). Presence of the pharmaceutical drug carbamazepine in coastal systems: Effects on bivalves. Aquat. Toxicol., 156, 74-87.

Almeida, A., Freitas, R., Calisto, V., Esteves, V.I., Schneider, R.J., Soares, A.M.V.M., Figueira, E., Campos, B., Barata, C. (2018). Effects of carbamazepine and cetirizine under an ocean acidification scenario on the biochemical and transcriptome responses of the clam Ruditapes philippinarum. Environ. Pollut., 235, 857-868.

Almeida, A., Freitas, R., Calisto, V., Esteves, V.I., Schneider, R.J., Soares, A.M.V.M., Figueira, E. (2015). Chronic toxicity of the antiepileptic carbamazepine on the clam Ruditapes philippinarum. Comp Biochem. Physiol. C Toxicol. Pharmacol., 172, 26-35.

Andrade, M., De Marchi, L., Soares, A.M.V.M., Rocha, R.J.M., Figueira, E., Freitas, R. (2019). Are the effects induced by increased temperature enhanced in Mytilus galloprovincialis submitted to air exposure? Sci. Total. Environ., 647, 431-440. assay applicable to acrylamide gels. Anal. Biochem., 44, 276-287.

549 increased sea water concentrations of $\mathrm{CO}_{2}$ on growth of the bivalve Mytilus edulis $\mathrm{L}$. Chemosphere, 62, 681-687. 
Bonnefille, B., Gomez, E., Courant, F., Escande, A., Fenet, H. (2018). Diclofenac in the marine environment: A review of its occurrence and effects. Mar. Pollut. Bull., 131, 496-506.

Carregosa, V., Velez, C., Soares, A.M.V.M., Figueira, E., Freitas, R. (2014). Physiological and biochemical responses of three Veneridae clams exposed to salinity changes. Comp. Biochem. Physiol. B Biochem. Mol. Biol., 177-178, 1-9.

Cheng, Y., Zheng, Y., Vandergheynst, J.S. (2011). Rapid quantitative analysis of lipids using a colorimetric method in a microplate format. Lipids, 46, 95-103.

Coppola, F., Tavares, D.S., Henriques, B., Monteiro, R., Trindade, T., Soares, A.M.V.M., Figueira, E., Polese, G., Pereira, E., Freitas, R. (2019). Remediation of arsenic from contaminated seawater using manganese spinel ferrite nanoparticles: Ecotoxicological evaluation in Mytilus galloprovincialis. Environ. Res., 175, 200-212.

Cruz, D., Almeida, A., Calisto, V., Esteves, V.I., Schneider, R.J., Wrona, F.J., Soares, A.M.V.M., Figueira, E., Freitas, R. (2016) Caffeine impacts in the clam Ruditapes philippinarum: Alterations on energy reserves, metabolic activity and oxidative stress biomarkers. Chemosphere, 160, 95-103.

Daughton, C.G., Ternes, T.A. (1999). Pharmaceuticals and personal care products in the environment: agents of subtle change? Environ. Health Perspect., 107, 907-938.

De Coen, W.M., Janssen, C.R. (1997). The use of biomarkers in Daphnia magna toxicity testing. IV. Cellular energy allocation: a new methodology to assess the energy budget of toxicant-stressed Daphnia populations. J. Aquat. Ecosyst. Stress Recov., 6, 43-55.

De Marchi, L., Neto, V., Pretti, C., Figueira, E., Chiellini, F., Morelli, A., Soares, A.M.V.M., Freitas, R. (2017). The impacts of seawater acidification on Ruditapes philippinarum sensitivity to carbon nanoparticles. Environ. Sci. Nano., 4, 1692-1704.

De Marchi, L., Neto, V., Pretti, C., Figueira, E., Chiellini, F., Morelli, A., Soares, A.M.V.M., Freitas, R. (2018). Toxic effects of multi-walled carbon nanotubes on bivalves: Comparison between functionalized and nonfunctionalized nanoparticles. Sci. Total. Environ., 622, 15321542. 
Dickson, A.G. (1990). Standard potential of the reaction: $\mathrm{AgCl}(\mathrm{s})+12 \mathrm{H} 2(\mathrm{~g})=\mathrm{Ag}(\mathrm{s})+\mathrm{HCl}$

579 (aq), and and the standard acidity constant of the ion HSO4- in synthetic sea water from 273.15 to 318.15 K. J. Chem. Thermodyn., 22, 113-127.

Dickson, A.G., Millero, F.J. (1987). A comparison of the equilibrium constants for the dissociation of carbonic acid in seawater media. Deep Sea Res. Part A. Oceanogr. Res. Pap., 34, 1733-1743.

Dubois, M.K., Gilles, A., Hamilton, J.K., Rebers, P.A., Sith, F. (1956). Calorimetric method for determination of sugars and related substances. Anal. Chem., 28, 350-356.

Durieux, E.D.H., Farver, T.B., Fitzgerald, P.S., Eder, K.J., Ostrach, D.J. (2011). Natural factors to consider when using acetylcholinesterase activity as neurotoxicity biomarker in Young-Of-Year striped bass (Morone saxatilis). Fish Physiol. Biochem., 37, 21-29.

Ellman, G.L., Courtney, K.O., Andres, V., Featherstone, R.M. (1961). A new and rapid 590 colorimetric determination of acetylcholinesterase activity. Biochem. Pharmacol., 7, 88-95.

Fabbri, E., Franzellitti, S. (2016). Human pharmaceuticals in the marine environment: focus on exposure and biological effects in animal species. Environ. Toxicol. Chem., 35, 799593 812.

Feely, R.A., Doney, S.C., Cooley, S.R. (2009). Ocean acidification: present conditions and 595 future changes in a high-CO2 world. Oceanography 22, 36-47. Res. 132, 361-370.

Freitas, R., Coppola, F., Costa, S., Pretti, C., Intorre, L., Meucci, V., Soares, A.M.V.M., 605 Solé, M. (2019a). The influence of temperature on the effects induced by Triclosan and Diclofenac in mussels. Sci. Total. Environ., 663, 992-999. 
Pretti, C., Solé, M. (2019b). Does salinity modulates the response of Mytilus galloprovincialis exposed to Triclosan and Diclofenac? Environ. Pollut., 251, 756-765.

Figueira, E., Soares, A.M.V.M. (2017a). Effects of seawater acidification and salinity alterations on metabolic, osmoregulation and oxidative stress markers in Mytilus galloprovincialis. Ecol. Indic., 79, 54-62.

Freitas, R., Coppola, F., Henriques, B., Wrona, F., Figueira, E., Pereira, E., Soares, A.M.V.M. (2017b). Does pre-exposure to warming conditions increase Mytilus galloprovincialis tolerance to Hg contamination?. Comp Biochem. Physiol. C Toxicol. Pharmacol., 203, 1-11. Wrona, F.J., Figueira, E., Soares, A.M.V.M. (2016). The impacts of pharmaceutical drugs under ocean acidification: New data on single and combined long-term effects of carbamazepine on Scrobicularia plana. Sci. Total. Environ., 541, 977-985. pharmaceuticals in the marine and coastal environment. Phil. Trans. R. Soc. B, 369, 2013-0572. determination of the endocrine disrupting compounds nonylphenol, nonylphenol ethoxylates, triclosan and bisphenol $\mathrm{A}$ in wastewater and sewage sludge by gas chromatography-mass spectrometry. J. Chromatogr. A, 1138, 32-41.

Gestoso, I., Arenas, F., Olabarria, C., (2016). Ecological interactions modulate responses of two intertidal mussel species to changes in temperature and pH. J. Exp. Mar. Bio. Ecol., 474, $116-125$.

Gonzalez-Rey, M., Bebianno, M.J. (2014). Effects of non-steroidal anti-inflammatory drug (NSAID) diclofenac exposure in mussel Mytilus galloprovincialis. Aquat. Toxicol., 148, 221-230. Schiedek, D., Sundelin, B., Readman, J.W., Macdonald, R.W. (2007). Interactions between climate change and contaminants. Mar. Pollut. Bull., 54, 1845-1856.

Habig, W.H., Pabst, M.J., Jakoby, W.B. (1974). Glutathione S-transferases. The first enzymatic step in mercapturic acid formation. J. Biol. Chem., 249, 7130-7139. 
Heberer, T. (2002). Tracking persistent pharmaceutical residues from municipal sewage to drinking water. J. Hydrol., 266, 175-189.

Henschel, K.P., Wenzel, A., Diedrich, M., Fliedner, A. (1997). Environmental hazard assessment of pharmaceuticals. Regul. Toxicol. Pharmacol., 25, 220-225.

IPCC, 2014: Climate Change 2014: Synthesis Report. Contribution of Working Groups I, II and III to the Fifth Assessment Report of the Intergovernmental Panel on Climate Change [Core Writing Team, R.K. Pachauri and L.A. Meyer (eds.)]. IPCC, Geneva, Switzerland, 151 pp Johansson, L.H., Borg, L.A. (1988). A spectrophotometric method for determination of catalase activity in small tissue samples. Anal. Biochem., 174, 331-336.

King, F.D., Packard, T.T. (1975). Respiration and the respiratory electron transport in marine zooplankton. Limnol. Oceanogr., 2849-2854.

Kolpin, D.W., Furlong, E.T., Meyer, M.T., Thurman, E.M., Zaugg, S.D., Barber, L.B., Buxton, H.T. (2002). Pharmaceuticals, hormones, and other organic wastewater contaminants in U.S. streams, 1999-2000: a national reconnaissance. Environ. Sci. Technol., 36, 1202-1211.

Landsdorp, D., Vree, T.B., Janssen, T.J., Guelen, P.J.M. (1990). Pharmacokinetics of rectal diclofenac and its hydroxy metabolites in man International Journal of Clinical Pharmacology Therapy and Toxicol., 28, 298-302.

Lehmann, J.M., Lenhard, J.M., Oliver, B.B., Ringold, G.M., Kliewer, S.A. (1997). Peroxisome proliferator-activated receptors alpha and gamma are activated by indomethacin and other non-steroidal anti-inflammatory drugs. J. Biol. Chem., 272, 3406-10.

Liu, S.H. (2019) Waste-Derived Biochar for CO2 Sequestration, biochar from biomass and waste fundamentals and applications, Book., 16, 295-304

Madikizela, L.M., Mdluli, P.S., Chimuka L. (2017). An Initial Assessment of Naproxen, Ibuprofen and Diclofenac in Ladysmith Water Resources in South Africa using Molecularly Imprinted Solid-Phase Extraction followed by High Performance Liquid ChromatographyPhotodiode Array Detection. S. Afr. J. Chem., 70, 145-153.

Matoo, O.B., Ivanina, A.V., Ullstad, C., Beniash, E., Sokolova, I.M. (2013). Interactive 662 effects of elevated temperature and $\mathrm{CO} 2$ levels on metabolism and oxidative stress in two 
common marine bivalves (Crassostrea virginica and Mercenaria mercenaria). Comp. Biochem. Physiol. A. Mol. Integr. Physiol., 164, 545-553.

Maulvault, A.L, Barbosa, V., Alves, R., Anacleto, P., Camacho, C., Cunha, S., Fernandes, J.O., Pousão, P., Rosa, R., Marques, A., Diniz, M. (2018). Integrated multi-biomarker responses of juvenile seabass to diclofenac, warming and acidification co-exposure Aquat. Toxicol., 202, $65-79$.

Mehrbach, C., Culberson, C.H., Hawley, J.E., Pytkowicx, R.M. (1973). Measurement of the apparent dissociation constants of carbonic acid in seawater at atmospheric pressure. Limnol. Oceanogr., 18, 897-907.

Mennillo, E., Casu, V., Tardelli, F., De Marchi, L., Freitas, R., Pretti, C. (2017). Suitability of cholinesterase of polychaete Diopatra neapolitana as biomarker of exposure to pesticides: In vitro characterization. Comp. Biochem. Physiol. Part - C Toxicol. Pharmacol., 191, 152-159. Simplified 2,4-dinitrophenylhydrazine spectrophotometric assay for quantification of carbonyls in oxidized proteins. Anal. Biochem, 458, 69-71. Occurence of neutral and acidic drugs in the effluents of canadian sewage treatment plants. Environ. Toxicol. Chem., 22, 2872.

Mezzelani, M., Gorbi, S., Da Ros, Z., Fattorini, D., d’Errico, G., Milan, M., Bargelloni, L., Regoli, F. (2016). Ecotoxicological potential of non-steroidal anti-inflammatory drugs (NSAIDs) in marine organisms: Bioavailability, biomarkers and natural occurrence in Mytilus galloprovincialis. Mar. Environ. Res. 121, 31-39.

Michaelidis, B., Ouzounis, C., Paleras, A., Pörtner, H.O. (2005). Effects of long-term moderate hypercapnia on acid - base balance and growth rate in marine mussels Mytilus galloprovincialis. Mar. Ecol. Prog. Ser. 293:109-118.

Moreira, A., Figueira, E., Libralato, G., Soares, A.M.V.M., Guida, M., Freitas, R. (2018c). development to As under varying salinity and temperature. Mar. Environ. Res., 140, 135-144. 

Bebianno, M.J. (2018a). Impacts of the combined exposure to seawater acidification and arsenic on the proteome of Crassostrea angulata and Crassostrea gigas. Aquat. Toxicol., 203, 117-129.

Moreira, A., Freitas, R., Figueira, E., Ghirardini, A.V., Soares, A.M.V.M., Radaelli, M., Guida, M., Libralato, G. (2018b). Combined effects of arsenic, salinity and temperature on Crassostrea gigas embryotoxicity. Ecotoxicol. Environ. Saf., 147, 251-259. with seawater acidification and the emerging contaminant diclofenac at the larval stage: a tale from the clam Ruditapes philippinarum. Chemosphere, 160, 293-302.

Munari, M., Matozzo, V., Gagn, F., Chemello, G., Riedl, V., Finos, L., Pastore, P., Badocco, D., Gabriella, M. (2018). Does exposure to reduced pH and diclofenac induce oxidative stress in marine bivalves? A comparative study with the mussel Mytilus galloprovincialis and the clam Ruditapes philippinarum. Environ. Pollut., 240, 925-937.

Nardi, A., Mincarelli, L.F., Benedetti, M., Fattorini, D., d'Errico, G., Regoli, F. (2017). Indirect effects of climate changes on cadmium bioavailability and biological effects in the Mediterranean mussel Mytilus galloprovincialis. Chemosphere 169, 493-502.

Nunes, B., Nunes, J., Soares, A.M.V.M., Figueira, E., Freitas, R. (2017) Toxicological effects of paracetamol on the clam Ruditapes philippinarum: exposure vs recovery. Aquat. Toxicol., 192, 198-206.

Ohkawa, H., Ohishi, N., Yagi, K. (1979). Assay for lipid peroxides in animal tissues by thiobarbituric acid reaction. Anal. Biochem., 95, 351-358.

Paglia, D.E., Valentine, W.N. (1967). Studies on quantitative and qualitative characterization of erythrocyte glutathione peroxidase. J. Lab. Clin. Med., 70, 158-169.

Quinn, B., Schmidt, W., Rourke, K.O., Hernan, R. (2011). Effects of the pharmaceuticals gemfibrozil and diclofenac on biomarker expression in the zebra mussel (Dreissena polymorpha) and their comparison with standardised toxicity tests. Chemosphere, 84, 657-663. 
Rahman, I., Kode, A., Biswas, S.K. (2007). Assay for quantitative determination of glutathione and glutathione disulfide levels using enzymatic recycling method. Nat. Protoc., 1, 3159-3165.

Robbins, L.L., Hansen, M.E., Kleypas, J.A., Meylan, S.C. (2010). CO2calc: A user-friendly seawater carbon calculator for windows, Mac OS X, and iOS (iPhone) (USGS Numbered Series No. 2010-1280), Open-File Report. U.S. Geological Survey, Reston, VA.

Robinson, H.W., Hogden, C.G. (1940). The biuret reaction in the determination of serum proteins. J. Biol. Chem., 135, 707-725.

Santos, L.H.M.L.M., Araújo, A.N., Fachini, A., Pena, A., Delerue-Matos, C., Montenegro, M.C.B.S.M. (2010). Ecotoxicological aspects related to the presence of pharmaceuticals in the aquatic environment. J. Hazard. Mater., 175, 45-95.

Schiedek, D., Sundelin, B., Readman, J.W., Macdonald, R.W. (2007). Interactions between climate change and contaminants. Mar. Pollut. Bull. 54, 1845-1856.

Schmidt, W., O'Rourke, K., Hernan, R., Quinn, B. (2011). Effects of the pharmaceuticals gemfibrozil and diclofenac on the marine mussel (Mytilus spp.) and their comparison with standardized toxicity tests. Mar. Pollut. Bull., 62, 1389-1395.

Schwaiger, J., Ferling, H., Mallow, U., Wintermayr, H., Negele, R.D. (2004). Toxic effects of the non-steroidal anti-inflammatory drug diclofenac: Part I: histopathological alterations and bioaccumulation in rainbow trout Aquat. Toxicol., 68, 141-150.

Serra-Compte, A., Maulvault, A.L., Camacho, C., Alvarez-Munoz, D., Barcelo, D., Rodriguez-Mozaz, S., Marques, A. (2018). Effects of water warming and acidification on bioconcentration, metabolization and depuration of pharmaceuticals and endocrine disrupting compounds in marine mussels (Mytilus galloprovincialis). Environ. Pollut., 236, 824-834.

Solé, M., Bonsignore, M., Rivera-Ingraham, G., Freitas, R. (2018). Exploring alternative biomarkers of pesticide pollution in clams. Mar. Pollut. Bull.,136: 61-67.

Solomon, S., Plattner, G.-K., Knuttic, R., Friedlingstein, P. (2009). Irreversible climate change due to carbon dioxide emissions. Pnas, 106 (6), 1704-1709.

Stumpf, M., Ternes, T.A., Haberer, K., Seel, P., Baumann, W. (1996). Determination of pharmaceutics in sewage plants and river water. Vom Wasser, 86, 291-303. 
Talmage, S.C, Gobler, C.J. (2009). The effects of elevated carbon dioxide concentrations on the metamorphosis, size, and survival of larval hard clams (Mercenaria mercenaria), bay scallops (Argopecten irradians), and Eastern oysters (Crassostrea virginica). Limnol Oceanogr, 54, 2072-2080.

Talmage, S.C., Gobler, C.J. (2011). Effects of elevated temperature and carbon dioxide on the growth and survival of larvae and juveniles of three species of Northwest Atlantic bivalves. PLoS ONE 6, 26941.

Ternes, T.A. (1998). Occurrence of drugs in German sewage treatment plants and rivers. Water Res., 32, 3245-3260.

Ternes, T.A. (2001). Analytical methods for the determination of pharmaceuticals in aqueous environmental samples. TrAC Trends Anal. Chem., 20, 419-434.

Velez, C., Figueira, E., Soares, A.M.V.M., Freitas, R. (2016b) Combined effects of seawater acidification and salinity changes in Ruditapes philippinarum. Aquat. Toxicol., 176, 760 $141-150$. partitioning and biochemical performance of Venerupis corrugata from a low contaminated system. Environ. Toxicol., 31, 569-583.

Xu, X., Yang, F., Zhao, L., Yan, X. (2016). Seawater acidification affects the physiological energetics and spawning capacity of the Manila clam Ruditapes philippinarum during gonadal maturation. Comp. Biochem. Physiol. A. Mol. Integr. Physiol., 196, 20-29.

Zhang, Y., Geißen, S., Gal, C. (2008). Carbamazepine and Diclofenac: Removal in 768 wastewater treatment plants and occurrence in water bodies. Chemosphere, 73, 1151-1161. 
Table 1- Carbonate system physicochemical parameters. Mean values ( \pm standard deviation) of $\mathrm{pH}$ and total alkalinity (AT) from weekly water sampling (temperature 17 ${ }^{\circ} \mathrm{C}$ and $\left.21{ }^{\circ} \mathrm{C}\right)$. Partial $\mathrm{CO} 2$ pressure (pCO2), carbonate ion concentrations $\left(\mathrm{CO}_{3}{ }^{2-}\right)$, saturation states of calcite $(\Omega \mathrm{Cal})$ and aragonite $(\Omega \mathrm{Ara})$ were calculated with $\mathrm{CO} 2 \mathrm{SYS}$ software (Robbins et al., 2010).

\begin{tabular}{|c|c|c|c|c|c|c|}
\hline Temperature (ㅇ) & $\mathrm{pH}$ & AT ( $\mu \mathrm{mol} / \mathrm{kg})$ & 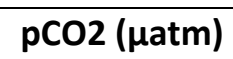 & $\mathrm{CO}_{3}{ }^{2-}(\mu \mathrm{mol} / \mathrm{kg})$ & $\Omega \mathrm{Cal}$ & $\Omega \mathrm{Ar}$ \\
\hline 17 & $8.04 \pm 0.04$ & $1813 \pm 339$ & $500 \pm 14.5$ & $87.56 \pm 0.23$ & $2.22 \pm 0.37$ & $1.39 \pm 0.23$ \\
\hline 21 & $7.71 \pm 0.04$ & $1815 \pm 258$ & $1072 \pm 331$ & $47.69 \pm 8.88$ & $1.22 \pm 0.23$ & $0.77 \pm 0.14$ \\
\hline
\end{tabular}

Table 2- Diclofenac concentrations in water ( $\mu \mathrm{g} / \mathrm{L})$, collected immediately after spiking after the $1^{\text {st }}, 2^{\text {nd }}$ and $3^{\text {rd }}$ water renewals, and in clams tissues (ng/g dry weight) at the end of the experimental period (37 days). Different letters denote statistical significance.

\begin{tabular}{l|c|c|c|c|c|}
\hline & \multicolumn{3}{c}{ Water } & \multicolumn{2}{c}{ Clams } \\
tissues
\end{tabular}


Figure captions

Figure 1: Respiration Rate (RR) in Ruditapes decussatus and Ruditapes philippinarum maintained for 30 days to actual conditions $\left(17^{\circ} \mathrm{C}, \mathrm{pH} 8.1\right)$ and predicted climate change conditions $\left(21^{\circ} \mathrm{C}, \mathrm{pH} 7.7\right)$, in the absence and presence of Diclofenac (DIC, 1 $\mu \mathrm{g} / \mathrm{L})$. Results are the means + standard errors. White bars represent noncontaminated organisms and black bars represent the contaminated ones. Significant differences $(p<0.05)$ between non- and DIC-exposed clams are represented in the figures with an asterisk; between climatic scenarios are represented with a cardinal and between species with a lower case letter (non-contaminated) and an upper case letter (contaminated).

Figure 2. A: Electron transport system (ETS) activity, B: Glycogen (GLY); C: Protein (PROT) and D: Lipids (LIP) concentrations, in Ruditapes decussatus and Ruditapes philippinarum maintained for 30 days to actual conditions $\left(17^{\circ} \mathrm{C}, \mathrm{pH} 8.1\right)$ and predicted climate change conditions $\left(21^{\circ} \mathrm{C}, \mathrm{pH} 7.7\right)$, in the absence and presence of Diclofenac (DIC, $1 \mu \mathrm{g} / \mathrm{L}$ ). Results are the means + standard errors. White bars represent noncontaminated organisms and black bars represent the contaminated ones. Statistical contrasts as in Figure 1.

Figure 3. A: Superoxide dismutase (SOD); B: Catalase (CAT); C: Glutathione peroxidase (GPx) and Glutathione-S-transferases (GSTs) activities, in Ruditapes decussatus and Ruditapes philippinarum maintained for 30 days to actual conditions $\left(17^{\circ} \mathrm{C}, \mathrm{pH} 8.1\right)$ and predicted climate change conditions $\left(21^{\circ} \mathrm{C}, \mathrm{pH} 7.7\right)$, in the absence and presence of Diclofenac (DIC, $1 \mu \mathrm{g} / \mathrm{L})$. Results are the means + standard errors. White bars represent non-contaminated organisms and black bars represent the contaminated ones. Statistical contrasts as in Figure 1. 
Figure 4. A: Lipid peroxidation (LPO) and B: protein carbonylation (PC) levels; C: reduced/oxidised glutathione (GSH/GSSG) ratio in Ruditapes decussatus and Ruditapes philippinarum maintained for 30 days to actual conditions $\left(17^{\circ} \mathrm{C}, \mathrm{pH} 8.1\right)$ and predicted climate change conditions $\left(21^{\circ} \mathrm{C}, \mathrm{pH} 7.7\right)$, in the absence and presence of Diclofenac (DIC, $1 \mu \mathrm{g} / \mathrm{L})$. Results are the means + standard errors. White bars represent non-contaminated organisms and black bars represent the contaminated ones. Statistical contrasts as in Figure 1.

Figure 5: Acetylcholinesterase (AChE) activity, in Ruditapes decussatus and Ruditapes philippinarum maintained for 30 days to actual conditions $\left(17^{\circ} \mathrm{C}, \mathrm{pH} 8.1\right)$ and predicted climate change conditions $\left(21^{\circ} \mathrm{C}, \mathrm{pH} 7.7\right)$, in the absence and presence of Diclofenac (DIC, $1 \mu \mathrm{g} / \mathrm{L})$. Results are the means + standard errors. White bars represent noncontaminated organisms and black bars represent the contaminated ones. Statistical contrasts as in Figure 1.

Figure 6: Centroids ordination diagram (PCO) based on DIC concentrations, physiological and biochemical parameters, measured in Ruditapes decussatus and Ruditapes philippinarum maintained for 30 days to actual conditions $\left(17^{\circ} \mathrm{C}, \mathrm{pH} 8.1\right)$ and predicted climate change conditions $\left(21^{\circ} \mathrm{C}, \mathrm{pH} 7.7\right)$, in the absence and presence of Diclofenac (DIC, $1 \mu \mathrm{g} / \mathrm{L})$. Results are the means + standard errors. White bars represent non-contaminated organisms and black bars represent the contaminated ones. Statistical contrasts as in Figure 1. Pearson correlation vectors $(r>0.85)$ of physiological and biochemical descriptors were provided as supplementary variables being superimposed on the top of the PCO graph ETS, GLY, PROT, LPO, PC, GSH/GSSG, CAT, GPx, GSTs, AChE. 


\section{$\mathbf{R R}$}

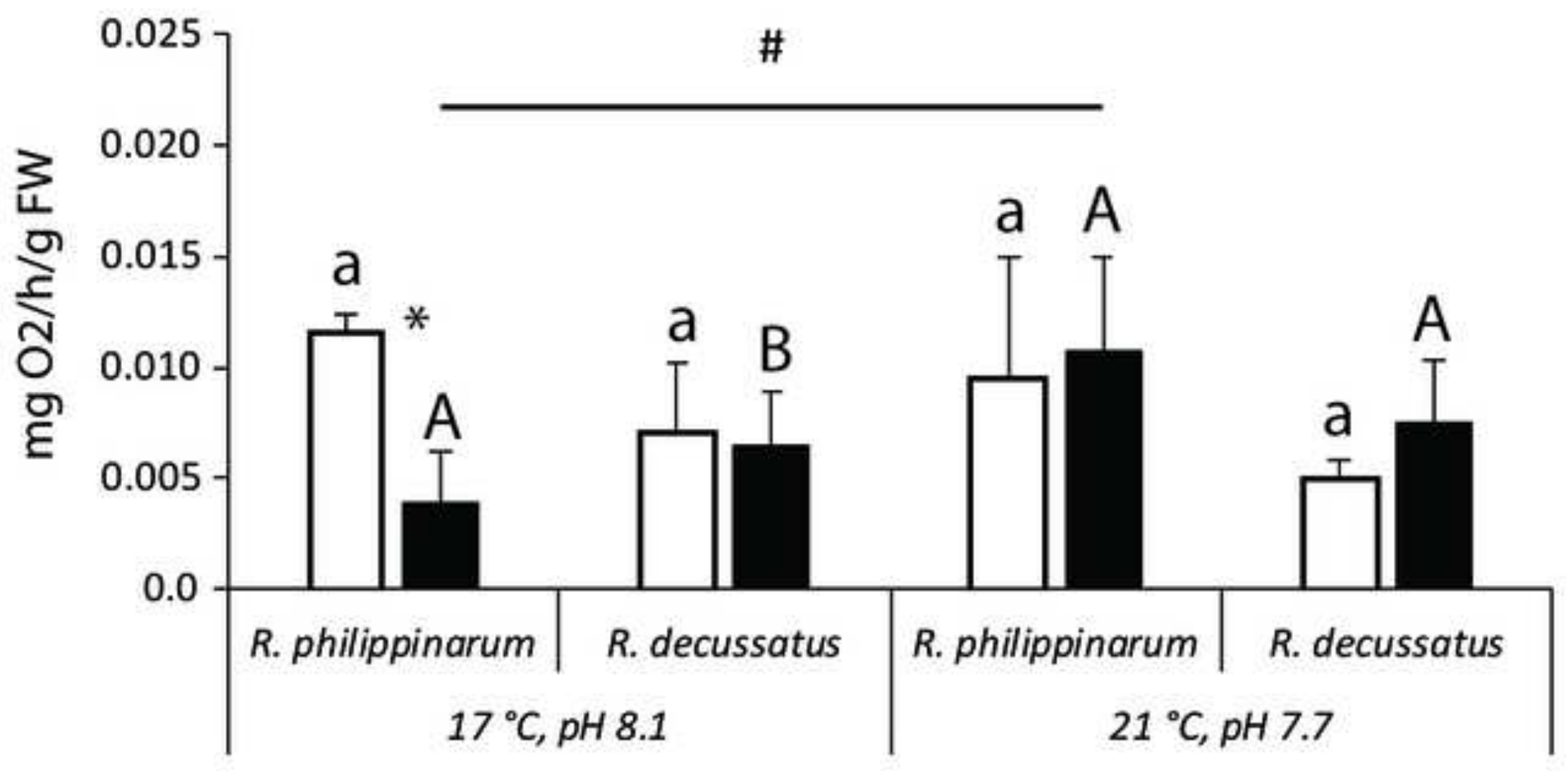


A

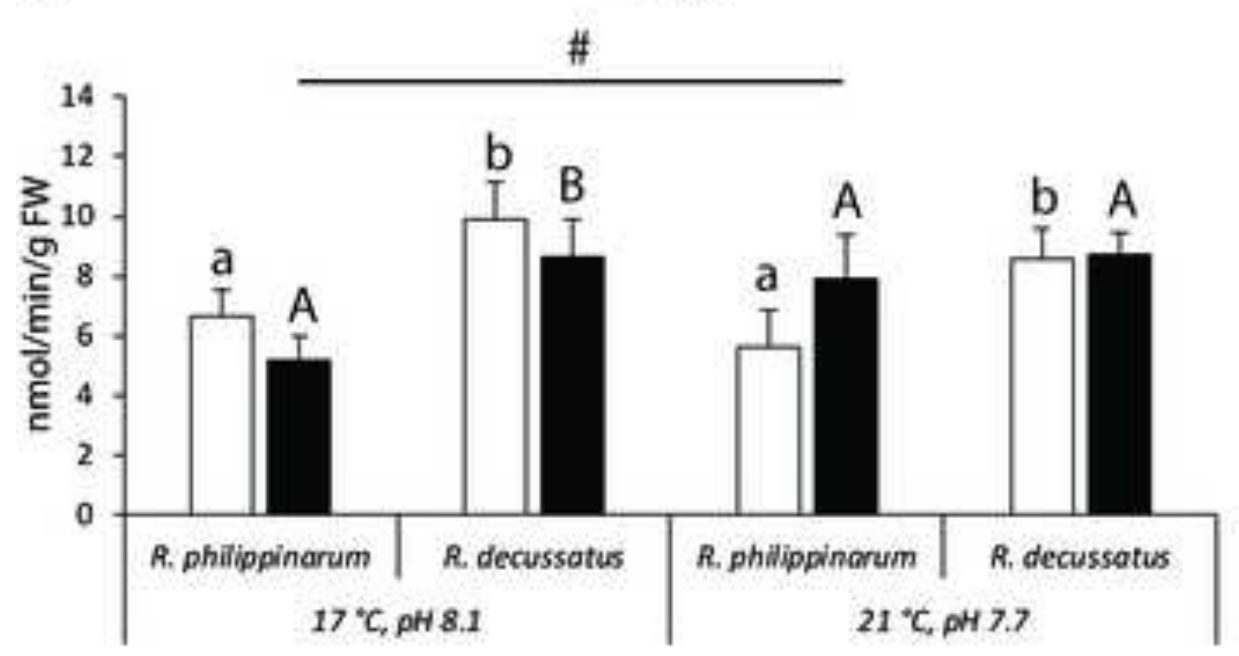

B

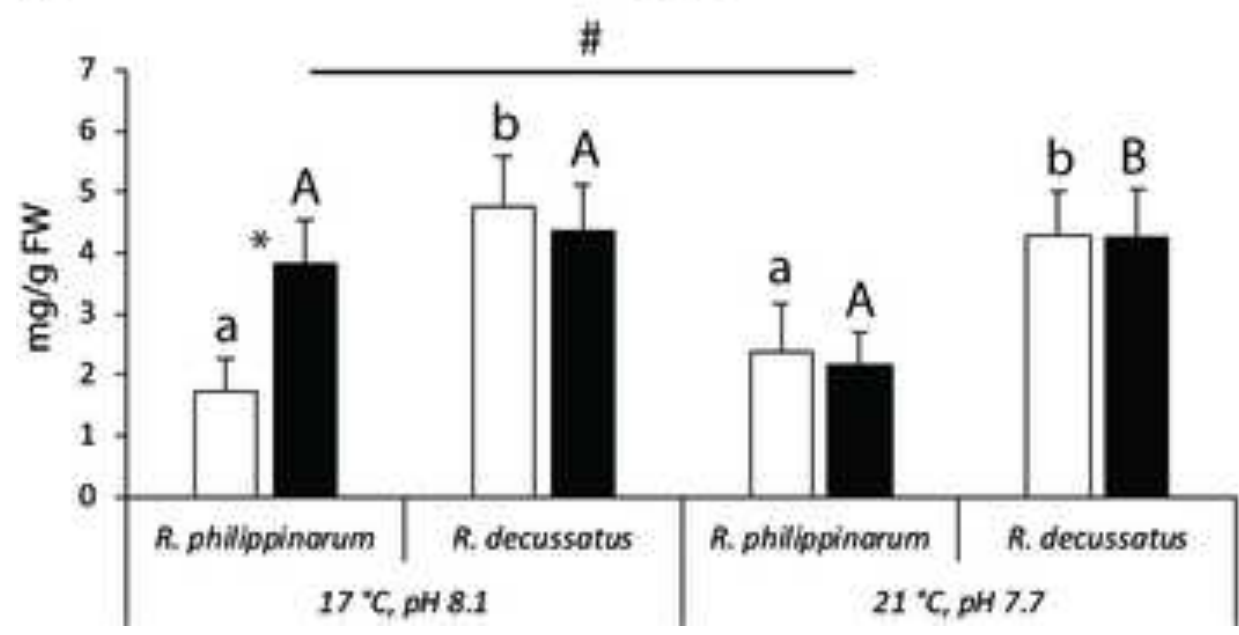

C

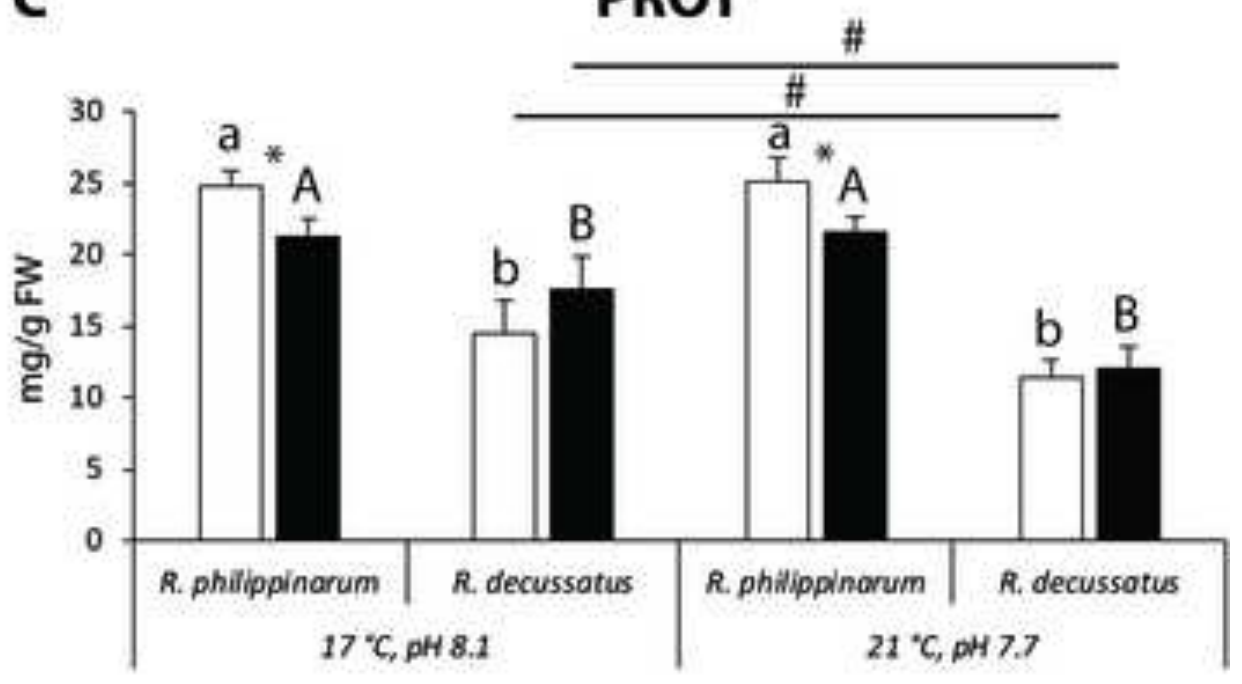

D

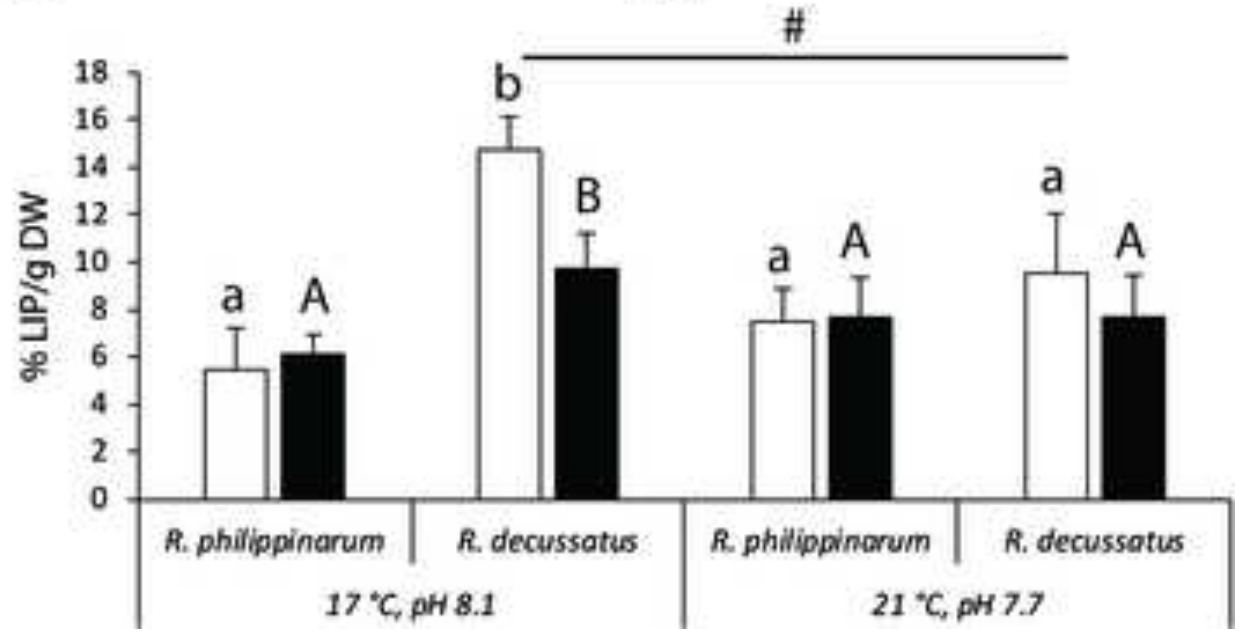


Click here to download high resolution image
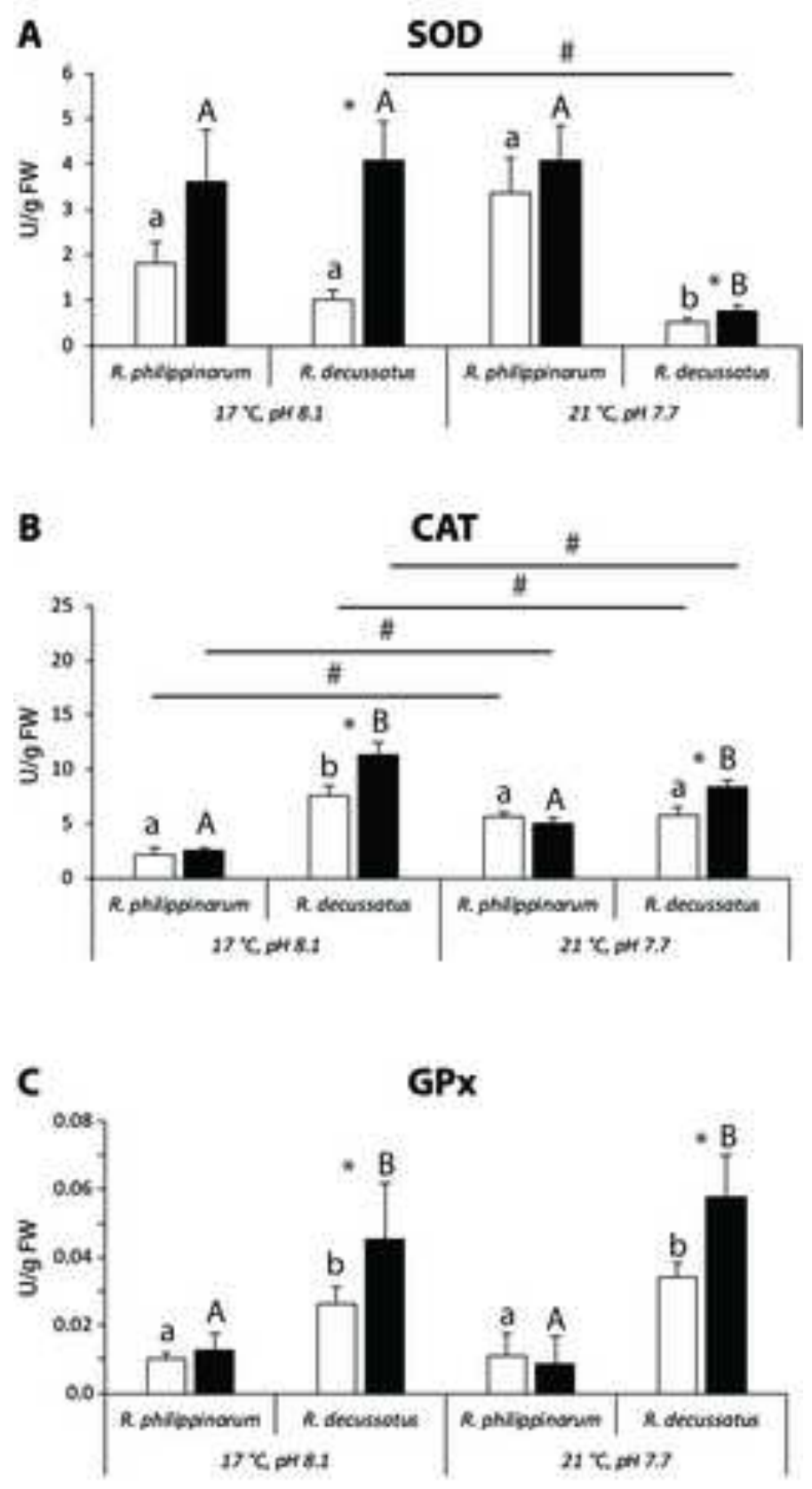

D

\section{GSTs}

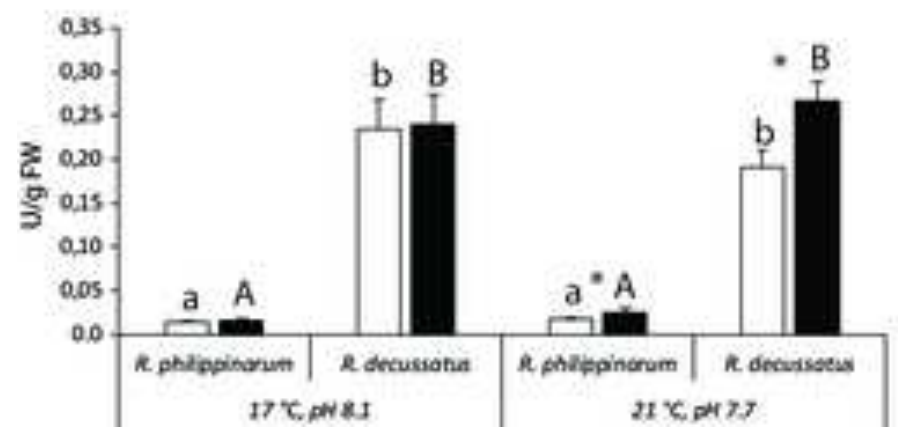


Click here to download high resolution image

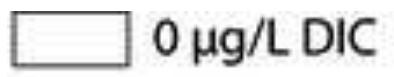

$1 \mu \mathrm{g} / \mathrm{L}$ DIC

A

LPO

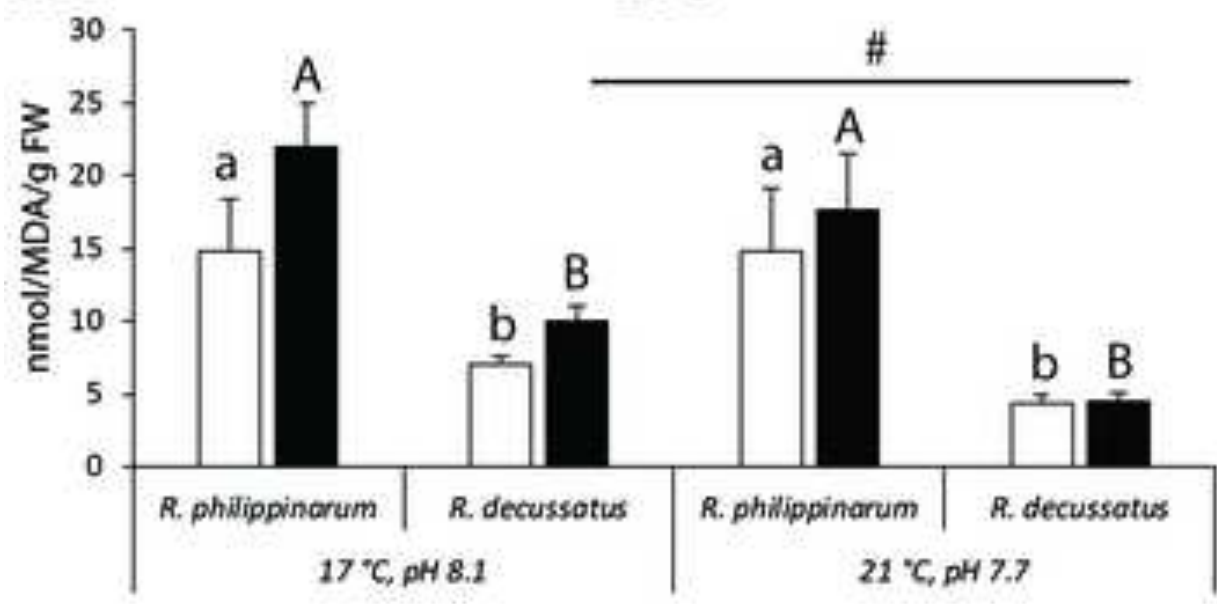

\section{PC}
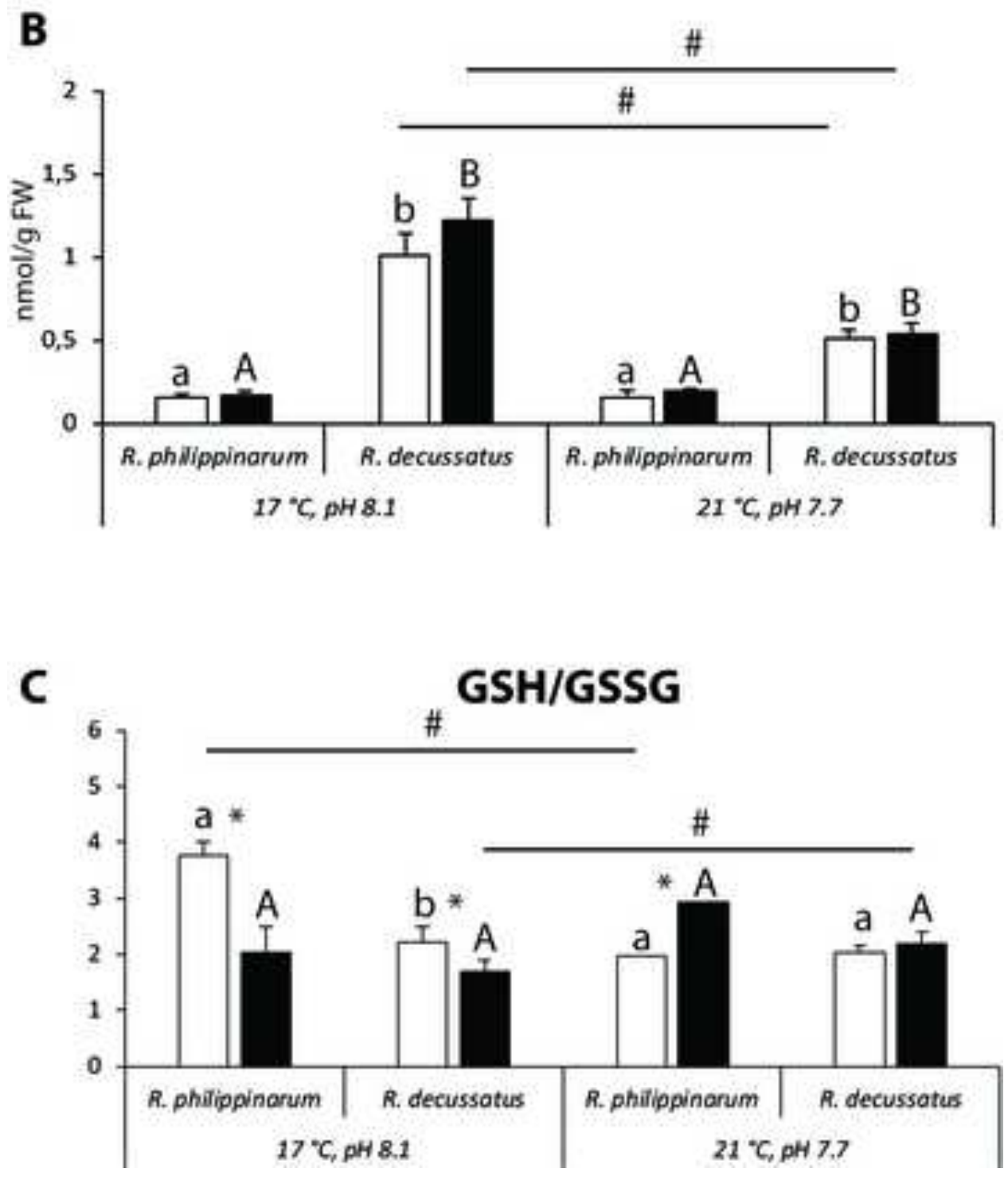


\section{AChE}

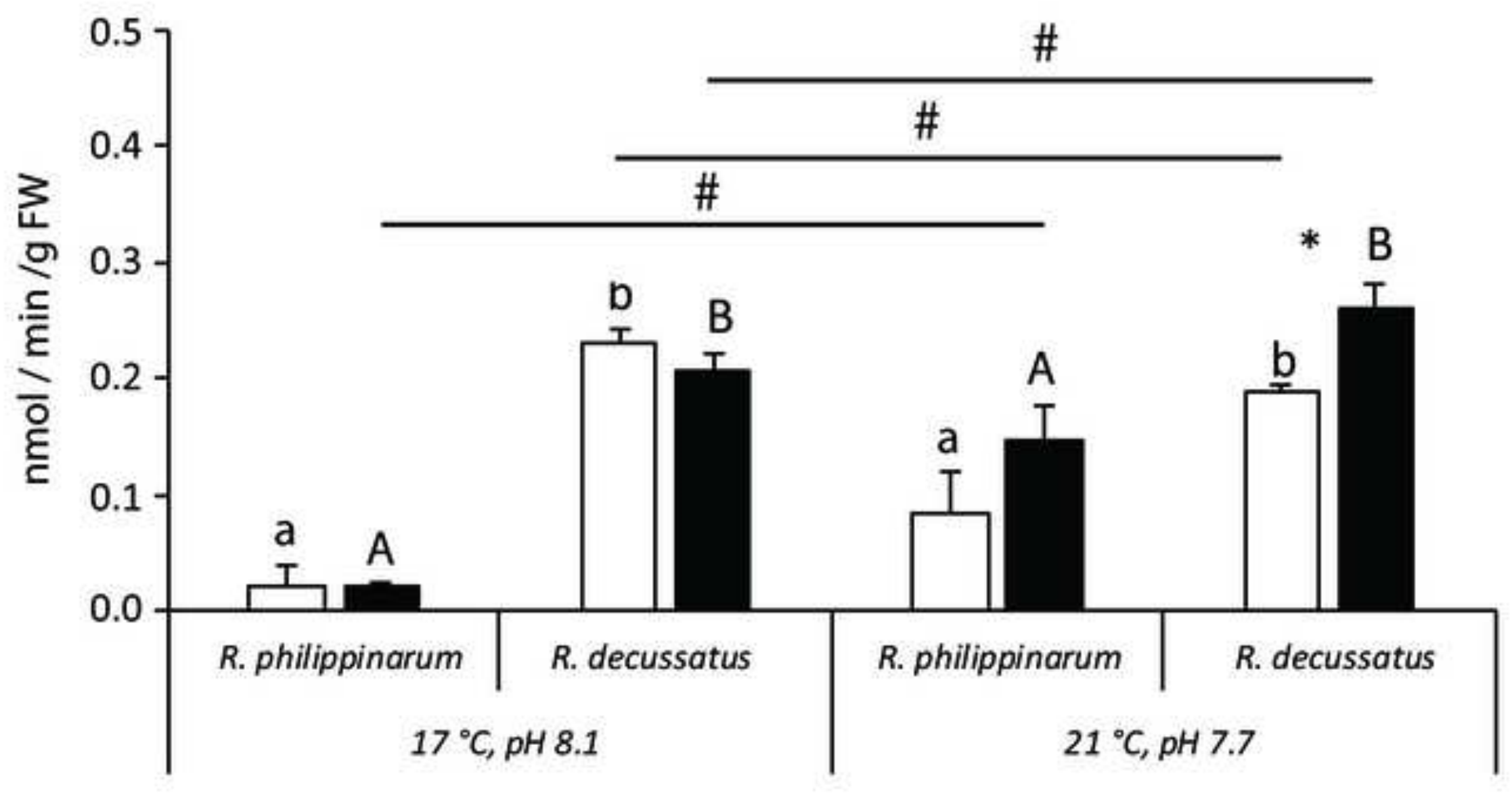


Click here to download high resolution image

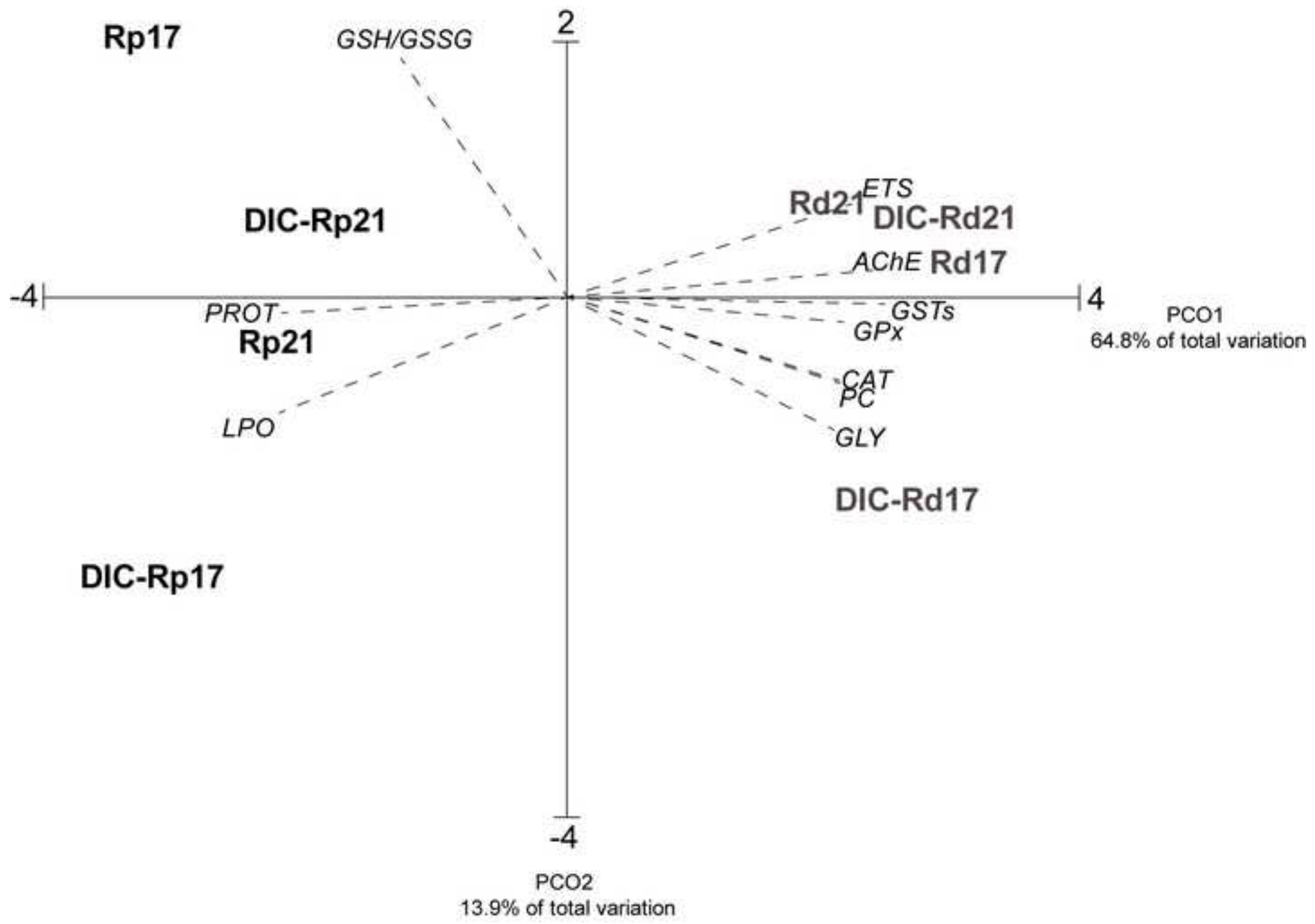

